\title{
Cardiovascular and neuropsychiatric risks of varenicline - Authors' reply
}

Citation for published version (APA):

Kotz, D., Viechtbauer, W., Simpson, C., van Schayck, C., West, R., \& Sheikh, A. (2016). Cardiovascular and neuropsychiatric risks of varenicline - Authors' reply. The Lancet Respiratory medicine, 4(3), [e10]. https://doi.org/10.1016/S2213-2600(16)00056-4

Document status and date:

Published: 01/01/2016

DOI:

10.1016/S2213-2600(16)00056-4

Document Version:

Publisher's PDF, also known as Version of record

Document license:

Taverne

Please check the document version of this publication:

- A submitted manuscript is the version of the article upon submission and before peer-review. There can be important differences between the submitted version and the official published version of record.

People interested in the research are advised to contact the author for the final version of the publication, or visit the DOI to the publisher's website.

- The final author version and the galley proof are versions of the publication after peer review.

- The final published version features the final layout of the paper including the volume, issue and page numbers.

Link to publication

\footnotetext{
General rights rights.

- You may freely distribute the URL identifying the publication in the public portal. please follow below link for the End User Agreement:

www.umlib.nl/taverne-license

Take down policy

If you believe that this document breaches copyright please contact us at:

repository@maastrichtuniversity.nl

providing details and we will investigate your claim.
}

Copyright and moral rights for the publications made accessible in the public portal are retained by the authors and/or other copyright owners and it is a condition of accessing publications that users recognise and abide by the legal requirements associated with these

- Users may download and print one copy of any publication from the public portal for the purpose of private study or research.

- You may not further distribute the material or use it for any profit-making activity or commercial gain

If the publication is distributed under the terms of Article $25 \mathrm{fa}$ of the Dutch Copyright Act, indicated by the "Taverne" license above, 
St. Michael's Hospital, Toronto, ON, M5B 1W8, Canada

1 Kotz D, Viechtbauer W, Simpson C, et al. Cardiovascular and neuropsychiatric risks of varenicline: a retrospective cohort study. Lancet Respir Med 2015; 3: 761-68.

2 Singh S, Loke YK, Spangler JG, Furberg CD. Risk of serious adverse cardiovascular events associated with varenicline: a systematic review and meta-analysis. CMAJ 2011; 183: 1359-66.

3 Stanbrook, Matthew (drstanbrook). So it may be that immediate quit period itself poses transient risks, rather than why you use to quit. Oct 30, 2015, 0050 h GMT. Tweet.

4 Kotz, Daniel (retweeted by rsjcguest). "In some instances, the HRs were not constant across the entire follow-up period (see paper), but always in the same direction. This is graphically displayed in the supplementary material." Nov 9, 2015. 1528 h GMT. Tweet.

5 Kotz, Daniel (retweeted by rsjcguest). "They should. We are currently looking at this in more detail as this question has been asked by others as well". Nov 9, 2015, 1524 h GMT. Tweet.

6 McEvoy JW, Blaha MJ, DeFilippis AP, et al. Cigarette smoking and cardiovascular events: role of inflammation and subclinical atherosclerosis from the MultiEthnic Study of Atherosclerosis. Arterioscler Thromb Vasc Biol 2015; 35: 700-09.

\section{Authors' reply}

In their Correspondence on our retrospective cohort study into the cardiovascular and neuropsychiatric risks of varenicline for smoking cessation, ${ }^{1}$ Lee Fidler and colleagues ask "whether propensity matching succeeded in balancing baseline covariates across groups". We have examined this important point further and take the opportunity to present additional data: the baseline characteristics of the two matched samples (nicotine replacement therapy vs bupropion and nicotine replacement therapy vs varenicline; table). Overall, trimming and matching of patients by propensity score succeeded in balancing potential confounders, although subtle differences remained. Notably, most present and previous diseases had a marginally higher prevalence rate at baseline (range $0 \cdot 1-1 \cdot 1 \%$ ) in the bupropion and varenicline group than in their matched nicotine replacement therapy group. Consequently, users of bupropion and varenicline might have been at slightly higher risk of the

\begin{tabular}{|c|c|c|c|c|}
\hline & \multicolumn{2}{|c|}{ NRT vs bupropion } & \multicolumn{2}{|c|}{ NRT vs varenicline } \\
\hline & $\begin{array}{l}\text { NRT } \\
(\mathrm{N}=6393)\end{array}$ & $\begin{array}{l}\text { Bupropion } \\
(\mathrm{N}=6393)\end{array}$ & $\begin{array}{l}\text { NRT } \\
(\mathrm{N}=50163)\end{array}$ & $\begin{array}{l}\text { Varenicline } \\
(\mathrm{N}=50163)\end{array}$ \\
\hline Age (years) & $37 \cdot 7(11 \cdot 2)$ & $37 \cdot 2(10 \cdot 8)$ & $37 \cdot 8(11 \cdot 9)$ & $37.6(11.2)$ \\
\hline \multicolumn{5}{|l|}{ Sex } \\
\hline Women & $3138(49 \cdot 1 \%)$ & 3095 (48.4\%) & $24720(49 \cdot 3 \%)$ & $23858(47 \cdot 6 \%)$ \\
\hline Men & $3255(50 \cdot 9 \%)$ & $3298(51.6 \%)$ & $25443(50 \cdot 7 \%)$ & $26305(52 \cdot 4 \%)$ \\
\hline Socioeconomic status* & $3 \cdot 0(1 \cdot 3)$ & $2 \cdot 9(1 \cdot 3)$ & $3 \cdot 0(1 \cdot 3)$ & $3 \cdot 0(1 \cdot 3)$ \\
\hline COPD & $341(5 \cdot 3 \%)$ & $355(5 \cdot 6 \%)$ & $3286(6 \cdot 6 \%)$ & $3554(7 \cdot 1 \%)$ \\
\hline Diabetes & $139(2 \cdot 2 \%)$ & $162(2 \cdot 5 \%)$ & $1946(3.9 \%)$ & $2114(4 \cdot 2 \%)$ \\
\hline Peptic ulcer disease & $82(1 \cdot 3 \%)$ & $119(1 \cdot 9 \%)$ & $968(1.9 \%)$ & $1105(2 \cdot 2 \%)$ \\
\hline Renal disease & $89(1.4 \%)$ & $146(2 \cdot 3 \%)$ & $1006(2 \cdot 0 \%)$ & $1178(2 \cdot 3 \%)$ \\
\hline Rheumatological disease & $82(1 \cdot 3 \%)$ & $87(1.4 \%)$ & $777(1 \cdot 5 \%)$ & $926(1 \cdot 8 \%)$ \\
\hline Cancer & $123(1 \cdot 9 \%)$ & $127(2 \cdot 0 \%)$ & $1074(2 \cdot 1 \%)$ & $1220(2 \cdot 4 \%)$ \\
\hline Alcohol misuse & $277(4 \cdot 3 \%)$ & $283(4 \cdot 4 \%)$ & $2446(4 \cdot 9 \%)$ & $2562(5 \cdot 1 \%)$ \\
\hline $\begin{array}{l}\text { Previous ischaemic heart } \\
\text { disease }\end{array}$ & $100(1.6 \%)$ & $100(1.6 \%)$ & $1161(2 \cdot 3 \%)$ & $1267(2 \cdot 5 \%)$ \\
\hline Previous cerebral infarction & $47(0 \cdot 7 \%)$ & $52(0 \cdot 8 \%)$ & $444(0.9 \%)$ & $463(0.9 \%)$ \\
\hline Previous heart failure & $6(0 \cdot 1 \%)$ & $9(0 \cdot 1 \%)$ & $72(0 \cdot 1 \%)$ & $78(0 \cdot 2 \%)$ \\
\hline $\begin{array}{l}\text { Previous peripheral vascular } \\
\text { disease }\end{array}$ & $28(0 \cdot 4 \%)$ & $30(0 \cdot 5 \%)$ & $254(0.5 \%)$ & $319(0 \cdot 6 \%)$ \\
\hline Previous arrhythmia & $51(0 \cdot 8 \%)$ & $69(1.1 \%)$ & $367(0.7 \%)$ & $470(0.9 \%)$ \\
\hline Previous depression & $2114(33 \cdot 1 \%)$ & $2137(33 \cdot 4 \%)$ & $15463(30 \cdot 8 \%)$ & $15340(30 \cdot 6 \%)$ \\
\hline Previous self-harm & $516(8 \cdot 1 \%)$ & $586(9 \cdot 2 \%)$ & 3997 (8.0\%) & $4254(8 \cdot 5 \%)$ \\
\hline \multicolumn{5}{|c|}{$\begin{array}{l}\text { Data are } \mathrm{n}(\%) \text { or mean (SD). NRT=nicotine replacement therapy. COPD=chronic obstructive pulmonary disease. } \\
\text { *Townsend index: } 1 \text { (lowest) to } 5 \text { (highest level of deprivation). }\end{array}$} \\
\hline
\end{tabular}

neuropsychiatric and cardiovascular events of interest during follow-up in our propensity score analyses. However, if such differences had biased the findings from our analyses, the bias would not have been in favour of varenicline. Nevertheless, we found no evidence of an increased risk of any neuropsychiatric or cardiovascular event associated with varenicline compared with nicotine replacement therapy in the propensity score analyses. ${ }^{1}$

DK has received an unrestricted grant from Pfizer for a smoking cessation trial outside of the submitted work and is supported by a research grant from the Ministry of Innovation, Science and Research of the German Federal State of North Rhine-Westphalia. OCPvS has received an unrestricted research grant from Pfizer outside of the submitted work. The manufacturers of varenicline and bupropion were not involved during any stage of this project. RW has received grants, personal fees, and non-financial support from Pfizer, GlaxoSmithKline, and Johnson \& Johnson, and personal fees from Novartis, outside of the submitted work. AS is supported by the Farr Institute, which is supported by a consortia of funders led by the Medical Research Council and
Commonwealth Fund; the views presented here are those of AS and not necessarily of the Commonwealth Fund, its directors, officers, or staff. All other authors declare no competing interests.

${ }^{*}$ Daniel Kotz, Wolfgang Viechtbauer, Colin Simpson, Onno C P van Schayck, Robert West, Aziz Sheikh

\section{Daniel.Kotz@med.uni-duesseldorf.de}

Institute of General Practice, Medical Faculty of the Heinrich-Heine-University Düsseldorf 40225 Düsseldorf, Germany (DK); Department of Family Medicine, CAPHRI School for Public Health and Primary Care, Maastricht University Medical Centre, Maastricht, Netherlands (DK, OCPvS, AS); MHeNS School for Mental Health and Neuroscience, Maastricht University, Maastricht, Netherlands (WV); Allergy \& Respiratory Research Group, Centre for Medical Informatics, Usher Institute of Population Health Sciences and Informatics, University of Edinburgh, Edinburgh, UK (DK, CS, OCPvS, AS); Cancer Research UK Health Behaviour Research Centre, University College London, London, UK (DK, RW); and Division of General Internal Medicine and Primary Care, Brigham and Women's Hospital/Harvard Medical School, Boston MA, USA (AS)

1 Kotz D, Viechtbauer W, Simpson C, et al Cardiovascular and neuropsychiatric risks of varenicline: a retrospective cohort study. Lancet Respir Med 2015; 3: 761-68. 